\title{
Concept of the International Project University: learning without borders
}

Irina Livshits, Vladimir Vasilyev

Irina Livshits, Vladimir Vasilyev, "Concept of the International Project University: learning without borders," Proc. SPIE 9289, 12th Education and Training in Optics and Photonics Conference, 92890B (17 July 2014); doi: $10.1117 / 12.2070284$

SPIE Event: 12th Education and Training in Optics and Photonics Conference, 2013, Porto, Portugal 


\title{
Concept of the International Project University "Learning without borders"
}

\author{
Irina Livshits, Vladimir Vasilyev \\ National Research University of Information Technologies, Mechanics and Optics, Russia, 197101, \\ Saint Petersburg, 49 Kronverkskiy pr.
}

\begin{abstract}
The proposed concept concerns master students education based on implementing projects. The total educational structure has feedback from students and professors and is based on using theory of automatic operation related to the education process.
\end{abstract}

Keywords: project based learning, education in photonics, learning without borders

\section{INTRODUCTION}

Almost all universities in the world are facing serious problems in education, especially in technical sciences. This situation could be easily explained by revolution in information sciences, which is replacing traditional educational approaches by new internet based approaches changing ratio of used sources in favor of internet rather than books and lectures. From the other side, today students loose their interest to classical education and try to get closer to the educational subject, so called "hands-on" approach, rather than theoretical issues. Youngsters prefer to get fast and real results which in most cases must have understandable application.

This situation has deep roots both in social sciences and in information technologies.

As it was shown in [3], today 4 generations act together:

Different generations have different values, interests, and activities that are distinct and depend upon of circumstances that prevailed during its time. Family, work, sex, gender roles, leaders, social environment etc are all different in different times leading to westerners labeling earlier generations as Generations $\mathrm{X}, \mathrm{Y}$ and $\mathrm{Z}$. Even before these generations, demographers talk about Veterans and Baby Boomers as separate generations. Let us find out the differences of the approach to education in these generations based upon their features.

\section{Veterans and Baby Boomers}

Those born between 1924-1966, they are not attending universities any more, this is why we are not going to discuss here their educational preferences in detail. But still there exists a set of special programs so called "University of the third age."

\section{Generation X}

Those born between 1966 and 1976 are referred to as Generation X. They came into their own during 1988-1994. The kids born in this period were labeled as latch-key kids as they were exposed to lots of divorces and day care centers. This is the generation that had the lowest voting participation. Newsweek commented on this generation as one that was least concerned with social issues surrounding it and it also did not listen to news and other programs on TV. The current population of Generation X stands at 41 million.

This is the generation characterized with a skeptic attitude. They always were concerned with what was there in it for them. They were however the best generation in terms of education and started to form families with care avoiding the mistakes committed by their parents. 


\section{Generation $\mathbf{Y}$}

Those born between 1977 and 1994 are referred to as Generation Y. This generation is characterized as the most polished and sophisticated with respect to technology. However, it is immune to traditional marketing and sales methods. This generation is racially and ethnically much more diverse than Generation $\mathrm{X}$ and is also much more segmented watching own TV programs. This is the generation that has been exposed to the internet, cable TV, satellite radio etc. Generation $\mathrm{Y}$ is less brand loyal and is much more flexible than Generation X. It is also very fashion and style conscious. As kids grew up on dual income, they are more involved with family purchases. The current population of Generation $\mathrm{Y}$ is 71 million.

\section{Generation Z}

Those born between 1995 and 2011 are referred to as Generation Z. Their current population is 23 million but is growing rapidly. This generation has been exposed to high advances in technology and has made use of most of the modern gadgets. The kids of this generation have grown in sophisticated media and computer world and are more net savvy than kids of earlier generation. These are the kids born after the demise of Soviet Union and the Gulf War and so have nothing to do with the Cold War. Generation Z is also referred to as Generation I (Internet) or as generation @ as it remains connected and has got the nickname of digital natives.

This is why when we plan to educate generations Y and Z (I, @) we have to base educational programs on modern information technologies.

As it was told before these generations from one side are very tolerant, but for education they prefer to make their own choice and hate any restrictions and pressure on the subjects. Many of these kids have a lot of different knowledge, sometimes with strange and occasional selection of subjects. Inside this social group there are many children "indigo", which makes these generations very special.

The situation requires changing of the educational approach in general to make it more attractive to Z-generation students. In Russia it is even more complex problem, because Russian Universities now have to penetrate into the International education system.

So, in general all students get a lot of theoretical knowledge, a set of technical facts, but they are really do not ready to use them to solving certain problems when they start their real job...

The goal is to adapt and transfer current educational system to new system which corresponds better to future industrial "use" of newly born specialists taking into account rapidly changing information media and growing total volume of knowledge in selected field.

Also important to keep students well educated in neighboring fields, and besides that - teach them working as a team, and teach them how to write and speak, and give them main ideas of management - to help them to be more effective in the modern industrial word as soon as possible after the graduation. The ideas graduates have to be both problem solvers and effective communicators which have creative and critical thinking.

\section{MAIN IDEA}

Main idea is to transfer educational process into the combination of learning and practicing the process of problem solving and the course content simultaneously.

This transfer process has to include the following steps, see Table.1: 
Table 1. PBL structure for education in NRU ITMO in Photonics

\begin{tabular}{|l|l|l|l|l|}
\hline Step 1 & Step 2 & Step 3 & Final step & \\
\hline $\begin{array}{l}\text { Formation } \\
\text { of projects - } \\
\text { problem } \\
\text { analysis }\end{array}$ & $\begin{array}{l}\text { Choosing a } \\
\text { Project - } \\
\text { independent } \\
\text { research }\end{array}$ & $\begin{array}{l}\text { Binding of the } \\
\text { project to } \\
\text { educational } \\
\text { base and } \\
\text { drawing up the } \\
\text { individual plan }\end{array}$ & $\begin{array}{l}\text { Implementation of } \\
\text { the project - } \\
\text { brainstorming, } \\
\text { discussions, } \\
\text { solution testing }\end{array}$ & $\begin{array}{l}\text { Defense } \\
\text { of the } \\
\text { project }\end{array}$ \\
\\
\hline
\end{tabular}

\section{GENERAL PROJECT GOALS AND LEVELS}

Project goals could be described as:

1. Ambitious - create a NEW concept and NEW system of engineering education;

2. Usefull - obtain high quality specialist ready for self-implementation of the projects;

3. Social - transfer the process of formal collecting knowledge (by listening lectures) into creative process of selfextracting knowledge for its immediate use to work on the certain project.

It is obvious that these goals increase responsibily of the university and makes life of the administration more complex changing it from general approach of ALL the students to -a very personal approach to EVERY INDIVIDUAL student as analogue - changing from «mass production» to unique («hand-made») specialist.

Depending on project levels listed below student diploma could be specially evaluated, for example by industrial company, etc.

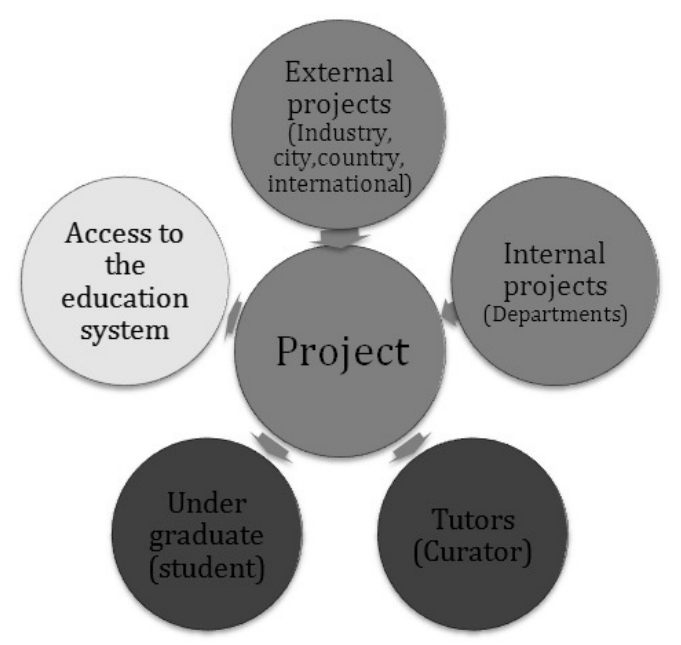

Fig.1. Links between educational elements in case of project based approach.

- Global

- International

- State

- Regional
- $\quad$ City

- University

- Chair

- Individual - any of listed above offered by a student him/her-self 


\section{CHANGING ROLES OF EDUCATORS}

\section{NRU ITMO APPROACH}

\subsection{NRU ITMO in brief}

National Research University of Information Technologies, Mechanics and Optics (NRU ITMO) is founded in 1910; Number of students -10000 persons;

Number of professors and additional personal - about 2500 persons

As it is presented in Fig.2, our University has plan to combine traditional education with new approaches, such as project-based education [1].

Students select a project and study all subjects, which are necessary to achieve the project goals.

We consider this as an active educational style, where student decides him/her self what subjects to take and when, depending on the project type.

This gives students a lot of freedom and initiative. They can use different types of education up to their choice: attending lectures, or distant education - it is allowed if they are successful in implementing projects.

In this practical and experimental type of education the priority is given to creativity in solving engineering problems and learning subjects through their practical use.

We call this type of education "Learning without borders" - as students will have no borders: political (they can participate in international projects); without strict educational frames - they follow their own schedule and took necessary subjects; they are also free to participate in the projects with professors and adults researchers - so they are not limited only to students projects. Some examples of projects are given.

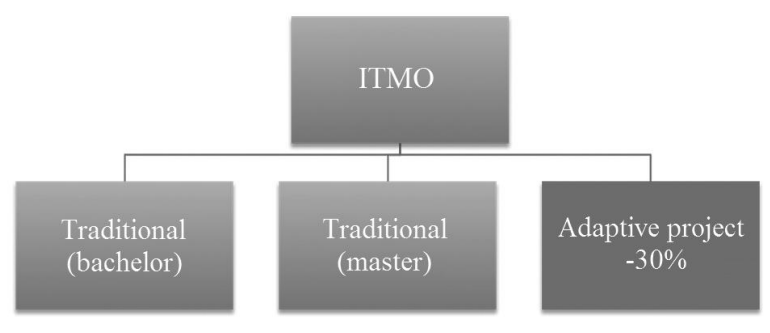

Fig.2. Ratio between traditional and project based programs at ITMO

\subsection{Why ITMO becomes "adaptive" and project based university after accepting this way:}

- Feedback structure

- Self-regulating structure

- Self-educating structure 


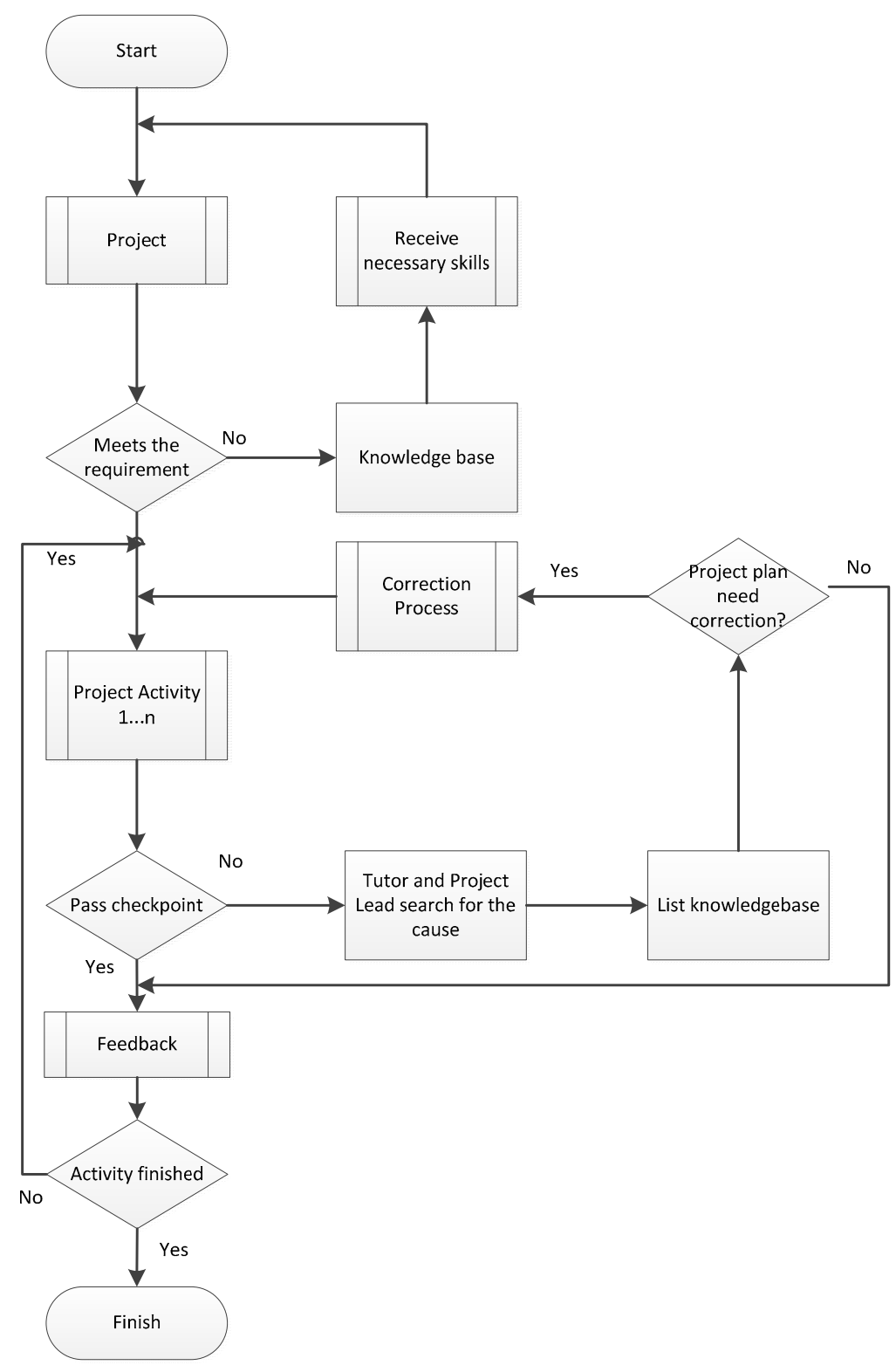

Fig.3 Main scheme

\subsection{Attractiveness of project based approach}

- $\quad$ Fast practical results;

- Graduates are better prepared for independent work;

- Financial profit - ability to receive money for projects commercialization;

- Youngsters are attracted by freedom which helps in development of creativity and initiative;

- General increasing of University effectiveness - non-effective directions of activity become visible and will be stopped.

\subsection{Expected disadvantages}

- New «perestroika»

- Complecated reorganization processes;

- Essential time and money expenses. 


\section{A way for internationalization (master program)- double degree with foreign university}

1. Exchange ideas

2. Letter of intent

3. Exchange of sillabuses

4. Adjusting programs and schedules

5. Signing agreement

6. Students exchanges

7. Professors exchanges

8. Educational process with necessary students mobility

9. Defense of diplomas (projects)

\section{RESUME AND EXPECTED EFFECTS}

Analysis of the idea and some experiments which started at our university in giving our master students more freedom and more choice in selecting project based education gives us hope for the following results of this approach:

- NRU ITMO becomes «a pioneer» and leading university of new type of education adaptive project based university;

- Quality of students education which are ready to work for industry will be improved;

- NRU ITMO will become more «visible» in the market of international education;

- University will be able to earn non-budget funds from sales of successful projects;

- Students will be able to create many «start-ups» from running and implemented projects;

- Links between industrial companies and NRU ITMO will be strengthened;

- Competition to enter NRU ITMO will increase and it will help to select higher qiality of future students to the university.

\section{ACKNOWLEDGEMENTS}

Thanks to Professor Nikolay Toivonen for his constant inspiration in innovations at our University. We appreciate valuable help of Ilya Mimorov, Dmitry Vorontsov and Anatoly Semenov from Lab of CAD of Opto-information \& Energy Saving Systems, NRU ITMO to current project.

\section{REFERENCES}

1. http://www.differencebetween.com/difference-between-generation-X-and-vs-generation-y-and-vs-generation-z/

2. www.photonics.com/Article.aspx?AID=53262\#sthash.vr4neeUY.dpuf

3. www.pblprojects.org

4. http//www.iods.pro 